\title{
Piperlongumine rapidly induces the death of human pancreatic cancer cells mainly through the induction of ferroptosis
}

\author{
YUKI YAMAGUCHI $^{1,2}$, TAKASHI KASUKABE ${ }^{1}$ and SHUNICHI KUMAKURA ${ }^{1}$ \\ ${ }^{1}$ Department of Medical Education and Research, Faculty of Medicine, Shimane University, Izumo, \\ Shimane 693-8501; ${ }^{2}$ Masuda Red Cross Hospital, Masuda, Shimane 698-8501, Japan
}

Received September 15, 2017; Accepted January 24, 2018

DOI: 10.3892/ijo.2018.4259

\begin{abstract}
Pancreatic cancer is one of the most lethal types of cancer with a mortality rate of almost $95 \%$. Treatment with current chemotherapeutic drugs has limited success due to poor responses. Therefore, the development of novel drugs or effective combination therapies is urgently required. Piperlongumine (PL) is a natural product with cytotoxic properties restricted to cancer cells by significantly increasing intracellular reactive oxygen species (ROS) levels. In the present study, we demonstrated that PL induced cancer cell death through, at least in part, the induction of ferroptosis, as the cancer cell-killing activity was inhibited by the antioxidant, $N$-acetylcysteine, ferroptosis inhibitors (ferrostatin-1 and liproxstatin-1) and the iron chelator, deferoxamine (DFO), but not by the apoptosis inhibitor, Z-VAD-FMK, or the necrosis inhibitor, necrostatin-1. Cotylenin A (CN-A; a plant growth regulator) exhibits potent antitumor activities in several cancer cell lines, including pancreatic cancer cell lines. We found that $\mathrm{CN}-\mathrm{A}$ and PL synergistically induced the death of pancreatic cancer MIAPaCa- 2 and PANC-1 cells for $16 \mathrm{~h}$. CN-A enhanced the induction of ROS by PL for $4 \mathrm{~h}$. The synergistic induction of cell death was also abrogated by the ferroptosis inhibitors and DFO. The present results revealed that clinically approved sulfasalazine (SSZ), a ferroptosis inducer, enhanced the death of pancreatic cancer cells induced by PL and the combined effects were abrogated by the ferroptosis inhibitors and DFO. SSZ further enhanced the cancer cell-killing activities induced by combined treatment with PL plus CN-A. On the other hand, the synergistic induction of cell death by PL and CN-A was not observed in mouse embryonic fibroblasts (MEFs), and SSZ did not enhance the death of MEFs induced by PL plus CN-A. These results suggest that the triple combined treatment with PL, CN-A and SSZ is highly effective against pancreatic cancer.
\end{abstract}

Correspondence to: Professor Takashi Kasukabe, Department of Medical Education and Research, Faculty of Medicine, Shimane University, Izumo 693-8501, Japan

E-mail: kasukabe@med.shimane-u.ac.jp

Key words: cotylenin A, piperlongumine, sulfasalazine, ferroptosis, pancreatic cancer cells

\section{Introduction}

Pancreatic cancer is a highly aggressive and almost lethal neoplasm among the most intractable of human malignancies with a 5-year survival rate of $<10 \%(1,2)$. Pancreatic cancer is the fourth leading cause of cancer-related mortality worldwide. The lethality of pancreatic cancer is characterized by the rapid invasion of the surrounding tissue, early metastatic disease, and poor responses to standard chemotherapy and radiotherapy (3). Surgical resection and chemotherapeutic regimens, which include gemcitabine, currently provide optimal clinical benefits. Gemcitabine, a cytidine analog that inhibits DNA synthesis and DNA repair, has been the reference drug for the treatment of this often fatal disease for $>10$ years (4). However, gemcitabine only produces a modest survival benefit (6-8 months) for patients with pancreatic cancer (4). The combination of 5-fluorouracil, leucovorin, irinotecan and oxaliplatin (FOLFIRINOX) has recently achieved more effective responses than gemcitabine in patients with advanced pancreatic cancer (5). However, the use of FOLFIRINOX results in greater toxicity than with treatment with gemcitabine and still only achieves a median overall survival of approximately 11 months (5). A number of novel anticancer drugs have been introduced over the past decade with the aim of improving the survival of patient with pancreatic cancer. However, despite continuous efforts to develop novel agents, none of the currently available chemotherapeutic agents have an objective response rate $>10 \%$ (6-8). Therefore, the development of novel and effective therapeutic agents or novel effective combination regimens is essential, and more effective and safe chemotherapeutic treatments are required.

Ras transformation renders cells sensitive to reactive oxygen species (ROS)-induced cell death (9) and pancreatic cancers exhibit an extremely high mutation rate of K-ras (>90\%) (10). Cotylenin A (CN-A), which has a diterpenoid tricarbocyclic skeleton, is produced by plant-pathogenic fungi and has been shown to induce the differentiation of human myeloid leukemia cells and apoptosis or the growth arrest of human carcinoma cells in the presence of interferon- $\alpha$ or rapamycin, respectively $(11,12)$. We recently reported that $\mathrm{CN}-\mathrm{A}$ significantly potentiated the arsenic trioxide-induced inhibition of cell growth in human breast cancer cells (13). We found that this synergistic growth inhibitory effect of $\mathrm{CN}-\mathrm{A}$ plus arsenic trioxide was significantly reduced by treatment with $\mathrm{N}$-acetylcysteine (NAC), a typical ROS scavenger (13). 
These findings thus suggest that $\mathrm{CN}-\mathrm{A}$ acts as a potent sensitizer of the antitumor activity of ROS inducers against solid tumors, including breast cancer and pancreatic cancer.

Ferroptosis has recently emerged as a new form of programmed cell death that has been characterized as non-apoptotic peroxidation-induced cell death contingent on the availability of iron and ROS (14-17). We recently reported that CN-A and phenethyl isothiocyanate (PEITC; a dietary anticarcinogenic compound and inducer of ROS) $(18,19)$ synergistically inhibited the proliferation of pancreatic cancer MIAPaCa-2 and PANC-1 cells (20). Combined treatment with CN-A and PEITC synergistically induced the generation of ROS. Antioxidants (NAC and trolox), ferroptosis inhibitors [ferrostatin-1 (Ferr-1) and liproxstatin-1 (Liprox)], and the lysosomal iron chelator deferoxamine (DFO) abolished synergistic cell death. An apoptosis inhibitor [Z-VAD-FMK (Z-VAD)] and the necrosis inhibitor necrostatin-1 (Nec-1) did not inhibit synergistic cell death (20). These findings indicated that synergistic cell death induced by combined treatment with CN-A and PEITC was mainly due to the induction of ferroptosis, whereas CN-A or PEITC alone did not induce the ferroptosis of pancreatic cancer cells. Therefore, there may be more effective combination treatment regimens using $\mathrm{CN}-\mathrm{A}$ and other ROS inducers against pancreatic cancer cells.

Piperlongumine (PL) is a biologically active alkaloid that largely exists in the long pepper (Piper longum L.). PL selectively induces the death of numerous cancer cell lines in vitro and in vivo, including pancreatic cancer, breast cancer, and leukemia, but does not exhibit anti-proliferative behavior in non-transformed cells (21-24). Therefore, PL is an attractive molecule for use in the development of novel treatment regimens for these types of cancer (25). PL directly binds to and inhibits the antioxidant enzyme, glutathione S-transferase Pi 1, resulting in elevated intracellular ROS levels and subsequent apoptotic cell death in cancers with no apparent toxicity to normal cells $(21,25)$. Apart from the induction of apoptosis, PL has been shown to cause cell cycle arrest (26), induce autophagy (27), and to inhibit migration and invasion $(28,29)$. However, the potential of PL to induce ferroptosis, particularly in pancreatic cancer cells, has not yet been demonstrated, at least to the best of our knowledge. In this study, we report that PL alone induces the ferroptotic death of pancreatic cancer cells and that a combined treatment with PL plus CN-A and/or a lower dose of sulfasalazine (SSZ; approved for clinical use for several diseases, such as rheumarthritis and one of the known ferroptosis inducers) (30) may further induce the ferroptotic death of pancreatic cancer cells.

\section{Materials and methods}

Cell culture. The human pancreatic cancer cell lines, MIAPaCa-2, PANC-1, CFPAC-1, and BxPC-3, were purchased from ATCC (Manassas, VA, USA). These pancreatic cancer cells were cultured in RPMI-1640 supplemented with $10 \%$ fetal bovine serum at $37^{\circ} \mathrm{C}$ in a humidified atmosphere of $5 \%$ carbon dioxide in air. Mouse embryonic fibroblasts (MEFs) were obtained from ATCC (ATCC CRL-2977) and cultured in Dulbecco's modified Eagle's medium (DMEM) containing $0.1 \mathrm{mM}$ non-essential amino acids, $0.05 \mathrm{mM}$ 2-mercaptoethanol and $10 \%$ fetal bovine serum at $37^{\circ} \mathrm{C}$ in a humidified atmosphere of $5 \%$ carbon dioxide in air.
Materials. CN-A was prepared as previously described (31). PL, 3-(4,5-dimethylthiazol-2yl)-2,5-diphenyltetrazolium bromide (MTT), NAC, Ferr-1, 3-methyladenine (3-MA), DFO, ciclopirox (CPX), RPMI-1640 medium, DMEM and arsenic trioxide were purchased from Sigma-Aldrich (St. Louis, MO, USA). Z-VAD, Nec-1 and Liprox were purchased from Selleckchem (Houston, TX, USA). PD146176 was obtained from Cayman Chemical Co. (Ann Arbor, MI, USA). SSZ was obtained from Tokyo Chemical Industry (Tokyo, Japan). Anti-glutathione peroxidase 4 (GPX4) antibody (Cat. no. ab125066) was obtained from Abcam (Tokyo, Japan). Anti-cleaved poly(ADP-ribose) polymerase (PARP) (Cat. no. 5625), anti-cleaved capase-3 (Cat. no. 9664), anti-LC3B (Cat. no. 2775) and anti- $\alpha / \beta$ tubulin (Cat. no. 2148) antibodies were purchased from Cell Signaling Technology (Danvers, MA, USA). Anti-p53 antibody (Cat. no. sc-126) was obtained from Santa Cruz Biotechnology (Santa Cruz, CA, USA).

Cell viability. Cell viability was assessed by MTT assay. The cells were seeded at $3 \times 10^{4}$ cells $/ \mathrm{ml}$ in a 24 -well multi-dish. After being cultured with or without the test compounds for $16 \mathrm{~h}, 500 \mu \mathrm{l}$ of DMSO were added to each well to solubilize formazan in viable cells. The plates were analyzed by measuring the optical density at $540 \mathrm{~nm}$, as previously described (12).

Measurement of glutathione (GSH) levels. Cellular GSH contents were measured using a GSH-Glo ${ }^{\mathrm{TM}}$ Glutathine Assay kit (Promega, Madison, WI, USA) according to the instructions provided by the manufacturer.

Western blot analysis. The cells were packed after washing with cold PBS and then lysed at a concentration of $1 \times 10^{7}$ cells $/ \mathrm{ml}$ in lysis buffer CelLytic ${ }^{\mathrm{TM}}$-M (Sigma-Aldrich) supplemented with a proteinase inhibitor cocktail and phosphatase inhibitor cocktail 1/2 (Sigma-Aldrich). Equal amounts of protein were separated on 10-20\% SDS-polyacrylamide gels (Wako, Osaka, Japan). Proteins were electrophoresed on gels and transferred onto Immobilon-P membranes (Millipore, Bedford, MA, USA) using the primary antibodies. An anti-rabbit or anti-mouse IgG HRP-linked antibody (Cell Signaling Technology) was used as a secondary antibody (1:2,000 dilution). The bands were identified by treatment with Immune-Star ${ }^{\mathrm{TM}}$ HRP chemiluminescence (Bio-Rad Laboratories, Hercules, CA, USA) for $5 \mathrm{~min}$ at room temperature and detected using a FujiLumino Image Analyser LAS-4000 system (Fuji Film Co., Ltd., Tokyo, Japan) (13). All western blots shown are representative of at least 3 independent experiments.

Preparation of positive control lysate for cleaved PARP and cleaved caspase-3 in western blot analysis. The MIAPaCa-2 cells were treated with $10 \mu \mathrm{g} / \mathrm{ml} \mathrm{CN-A}$ and $3 \mu \mathrm{M}$ arsenic trioxide for $72 \mathrm{~h}$. Whole cell lysate was obtained and used in western blot analysis as previously described (13).

Measurement of ROS generation. The production of ROS was monitored using a Muse cell analyzer (Millipore, Billerica, MA, USA), and the experimental protocol followed the description provided with the kit (Muse Oxidative Stress kit, Millipore). The MIAPaCa-2 cells were treated with the indicated drugs for $4 \mathrm{~h}$ to induce ROS production, and ROS levels 
B<smiles>COc1cc(/C=C/C(=O)N2CCC=CC2=O)cc(OC)c1OC</smiles>

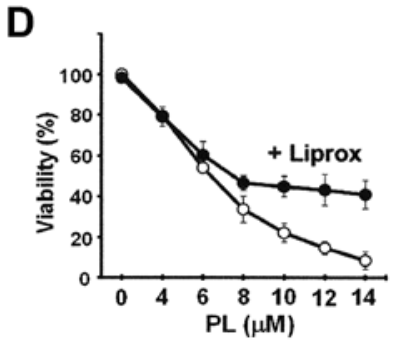

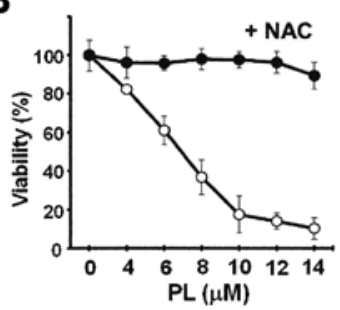

E

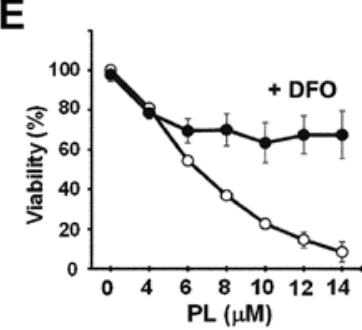

C

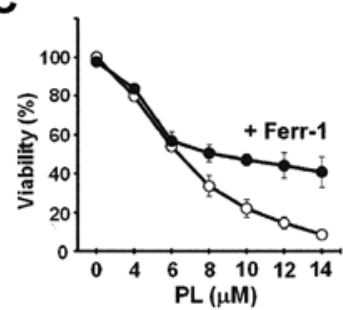

F
G

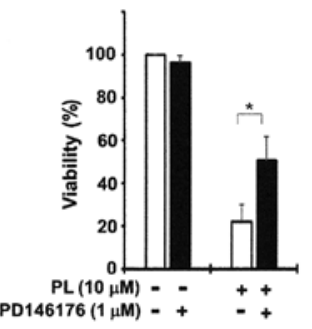

H

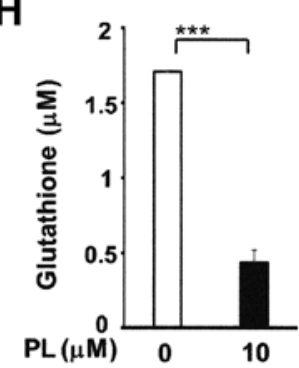

I

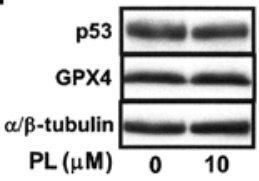

J

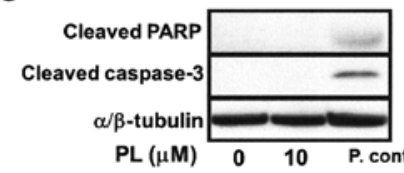

K

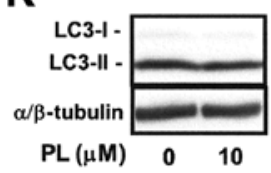

Figure 1. Effects of ferroptosis inhibitors on the piperlongumine (PL)-induced death of PANC-1 cells. (A) Structure of PL. PANC-1 cells (3x104 cells $/ \mathrm{ml})$ were cultured with the indicated concentrations of PL in the absence (open circles) or presence of (B) $3 \mathrm{mM} N$-acetylcysteine (NAC), (C) $1 \mu \mathrm{M}$ of ferrostatin-1 (Ferr-1), (D) $1 \mu \mathrm{M}$ of liproxstatin-1 (Liprox), (E) or $0.2 \mathrm{mM}$ deferoxamine (DFO) (closed circles) for $16 \mathrm{~h}$. The MIAPaCa-2 cells were treated with $10 \mu \mathrm{M}$ PL in the presence or absence of (F) $1.25 \mu \mathrm{M}$ ciclopirox (CPX) or (G) $1 \mu \mathrm{M}$ PD146176 for $16 \mathrm{~h}$. The cells were treated with NAC, Ferr-1, Liprox, DFO, CPX, or PD146176 for $2 \mathrm{~h}$ prior to PL treatment. Cell viability was then assessed by MTT assay. (H) Glutathione (GSH) levels in MIAPaCa-2 cells (8,000 cells/well) treated with PL for $4 \mathrm{~h}$. Values are expressed as the means \pm standard deviation of 3 measurements. Western blot analyses for (I) p53 and GPX4, (J) cleaved PARP and cleaved caspase-3, and (K) LC3-I/II proteins. The MIAPaCa-2 cells were cultured with or without $10 \mu \mathrm{M}$ PL for $16 \mathrm{~h}$. P.cont, positive control for cleaved PARP and cleaved caspase-3 [MIAPaCa-2 cells were treated with $10 \mu \mathrm{g} / \mathrm{ml} \mathrm{CN}-\mathrm{A}$ and $3 \mu \mathrm{M}$ arsenic trioxide for $72 \mathrm{~h}$ as previously described (13)]. Whole cell lysates were used for western blot analysis. The protein expression of $\alpha / \beta$-tubulin served as the loading control. Similar results were obtained in two additional experiments. ${ }^{*} \mathrm{P}<0.05,{ }^{* *} \mathrm{P}<0.01$ and ${ }^{* * * *} \mathrm{P}<0.001$.

were then measured using the Muse Oxidative Stress kit. Two populations of cells are distinguished in this assay: ROS (-) (live cells) and ROS (+) (cells exhibiting ROS).

Measurement of Annexin V-positive cells. Annexin V staining and the detection of Annexin V-positive cells were performed using the Muse cell analyzer, and the experimental protocol followed the description provided with the kit (Muse Annexin V \& Dead Cell Assay kit) (Millipore). The assay utilizes Annexin V to detect phosphatidylserine (PS) on the external membranes of apoptotic cells.

Statistical analysis. Values were compared using a two-tailed Student's t-test. Differences between the means were considered to be significant when P-values were $<0.05$.

\section{Results}

$P L$ induces the ferroptotic death of human pancreatic cancer cells. The PANC-1 cells were pre-treated with the ROS scavenger, NAC, the ferroptosis inhibitors (Ferr-1 and Liprox), or the iron chelator, DFO, for $2 \mathrm{~h}$, and were then further cultured in the presence or absence of PL for $16 \mathrm{~h}$. PL dose-dependently decreased PANC-1 cell viability: $14 \mu \mathrm{M}$ PL decreased cell viability to approximately $10 \%$ of the control. Consistent with findings from previous studies indicating that increased ROS levels are critical for cell death induced by PL $(21,22,25)$, NAC (3 mM) almost completely abrogated the PL-induced decrease in the viability of the PANC-1 cells (Fig. 1B). Ferroptosis is a recently recognized ROS- and iron-dependent form of regulated cell death that is accompanied by the accumulation of lipid 

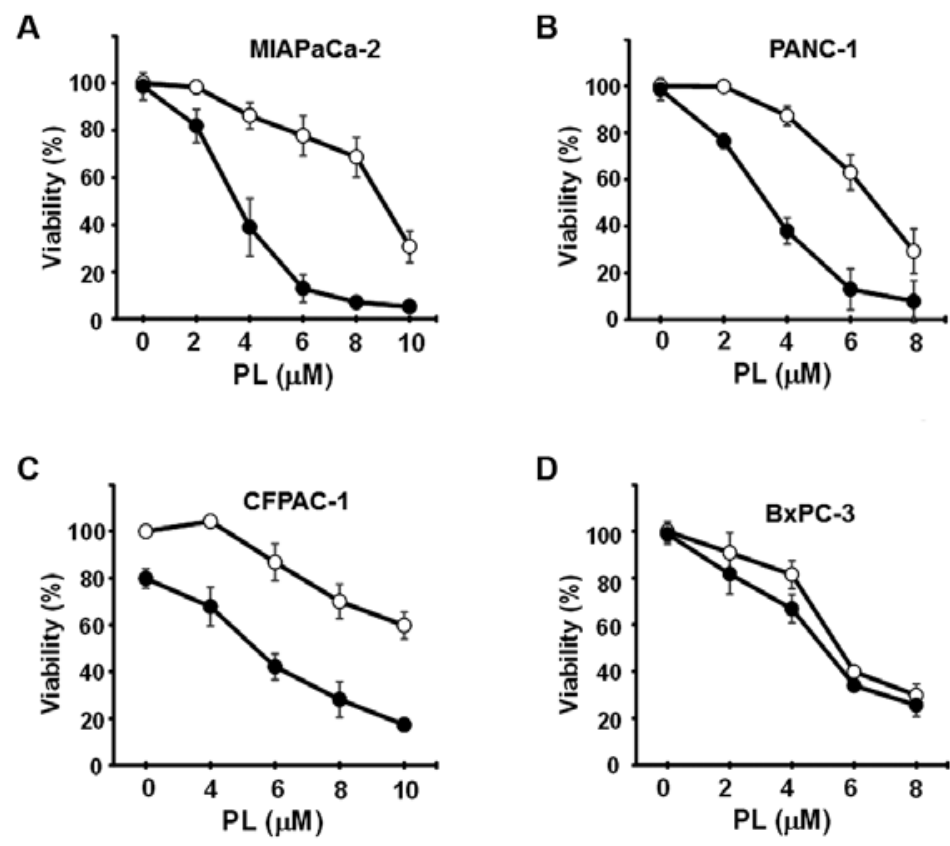

Figure 2. Effects of combined treatment with piperlongumine (PL) and cotylenin A (CN-A) on the viability of the MIAPaCa-2, PANC-1, CFPAC-1 and BxPC-3

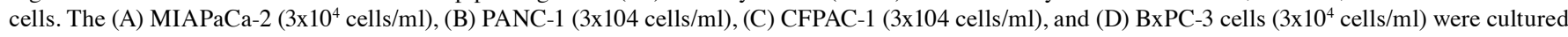
with PL in the absence (open circles) or presence of $15 \mu \mathrm{g} / \mathrm{ml}$ (closed circles) CN-A for $16 \mathrm{~h}$. Treatment with CN-A alone was shown as a closed circle at the $0 \mu \mathrm{M}$ PL position. Cell viability was then assessed by MTT assay. Values are expressed as the means \pm standard deviation of 3 measurements.

peroxidation products (21). Since this process may be inhibited by lipid peroxidation inhibitors (Ferr-1 and Liprox) and an iron chelator (DFO), we examined the effects of these ferroptosis inhibitors. As shown in Fig. 1C and D, Ferr-1 $(1 \mu \mathrm{M})$ and Liprox $(1 \mu \mathrm{M})$ significantly abolished PL $(>8 \mu \mathrm{M})$-induced cell death. DFO $(0.2 \mathrm{mM})$ also potently inhibited PL-induced cancer cell death. The viability of the PANC-1 cells following treatment with PL $(14 \mu \mathrm{M})$ in the presence of DFO was still $>60 \%$ (Fig. 1E). CPX (another intracellular iron chelator) also significantly reduced PL-induced cancer cell death (Fig. 1F). Similar results were also obtained when cell viability was measured by trypan blue dye exclusion assay (data not shown). Similar results were also obtained with the MIAPaCa-2 cells (data not shown). Consistent with the established role for lipoxygenase-catalyzed lipid hydroperoxidation for ferroptosis $(17,33)$, we observed that treatment with the lipoxygenase inhibitor, PD146176, prevented the cancer cells from undergoing PL-induced cell death (Fig. 1G). Intracellular GSH is a very important endogenous antioxidant used in the defense against ferroptosis $(16,33)$. Thus, we examined whether PL can deplete GSH in the MIAPaCa-2 cells. The content of cellular GSH in the cells treated with $10 \mu \mathrm{M}$ PL for $4 \mathrm{~h}$ was markedly depleted (Fig. 1H). Ferroptosis inducers preferentially kill cancer cells that accumulate mutant $\mathrm{p} 53$ protein $(32,33)$. Regarding this point, we noted that all of the pancreatic cancer cell lines used in this study expressed mutant p53, although PL had no obvious effect on the amount of p53 (Fig. 1I). PL did not decrease GPX in pancreatic cancer cells (Fig. 1I). However, GSH is a co-factor for GPX activity and GSH-depleting reagents inhibit GPX activity (16). Since we actually found that PL markedly depleted GSH (Fig. 1H), these results suggest that PL may inhibit GPX activity. PL did not induce the expression of typical apoptotic markers, such as cleaved PARP and cleaved caspase-3 (Fig. 1J). PL also did not affect the LC3-II/LC3-I ratio, an indicator of autophagy induction (Fig. 1K). These results thus suggest that PL alone induces cancer cell death through, at least in part, the induction of ferroptosis in pancreatic cancer cells.

$C N-A$ and $P L$ synergistically induce the death of pancreatic cancer MIAPaCa-2 and PANC-1 cells. We have recently reported that combined treatment with $\mathrm{CN}-\mathrm{A}$ and PEITC (another ROS inducer) induced the ferroptotic death of MIAPaCa-2 and PANC-1 cells, whereas PEITC alone, even at higher concentrations, did not (20). In this study, we examined whether CN-A enhances the PL-induced death of pancreatic cancer cell lines. The MIAPaCa-2, PANC-1, CFPAC-1 and BxPC-3 cells were cultured with or without CN-A, PL, or $\mathrm{CN}-\mathrm{A}$ plus PL for $16 \mathrm{~h}$. Treatment with $\mathrm{CN}-\mathrm{A}$ alone was shown as a closed circle at the $0 \mu \mathrm{M}$ PL position (Fig. 2). CN-A and PL synergistically reduced the viability of the MIAPaCa-2 and PANC-1 cells (Fig. 2A and B). Although PL alone, even at a higher concentration $(8 \mu \mathrm{M})$, reduced the viability of the MIAPaCa-2 cells to $\sim 70 \%$ and CN-A $(15 \mu \mathrm{g} / \mathrm{ml})$ alone did not influence the viability of the MIAPaCa-2 cells, PL at 4,6 , or $8 \mu \mathrm{M}$ reduced the viability of the MIAPaCa- 2 cells to $\sim 40,15$, or $10 \%$, respectively, in the presence of CN-A $(15 \mu \mathrm{g} / \mathrm{ml})$ (Fig. 2A). The synergistic induction of cell death induced by CN-A plus PL was also observed in the PANC-1 cells (Fig. 1B). CN-A and PL synergistically induced the death of CFPAC-1 cells (Fig. 2C). On the other hand, CN-A only slightly enhanced the PL-induced death of BxPC-3 cells, which did not contain the K-ras mutation (Fig. 2D).

$C N$-A enhances the PL-induced ferroptotic death of pancreatic cancer cells. We then investigated whether the synergistic induction of cancer cell death induced by combined treatment with CN-A and PL was due to the induction of ferroptosis. 

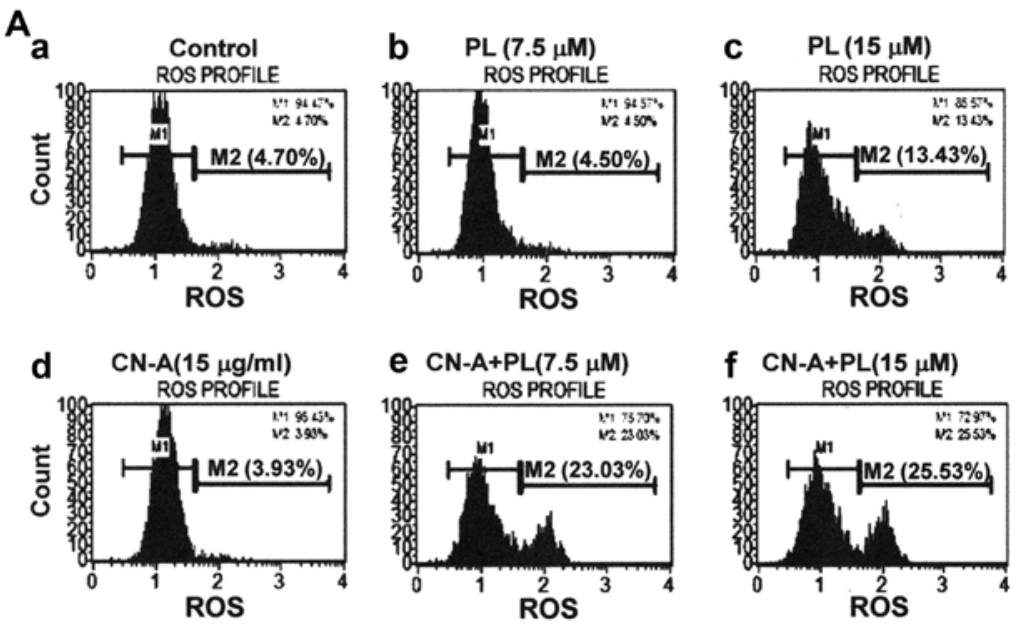

B
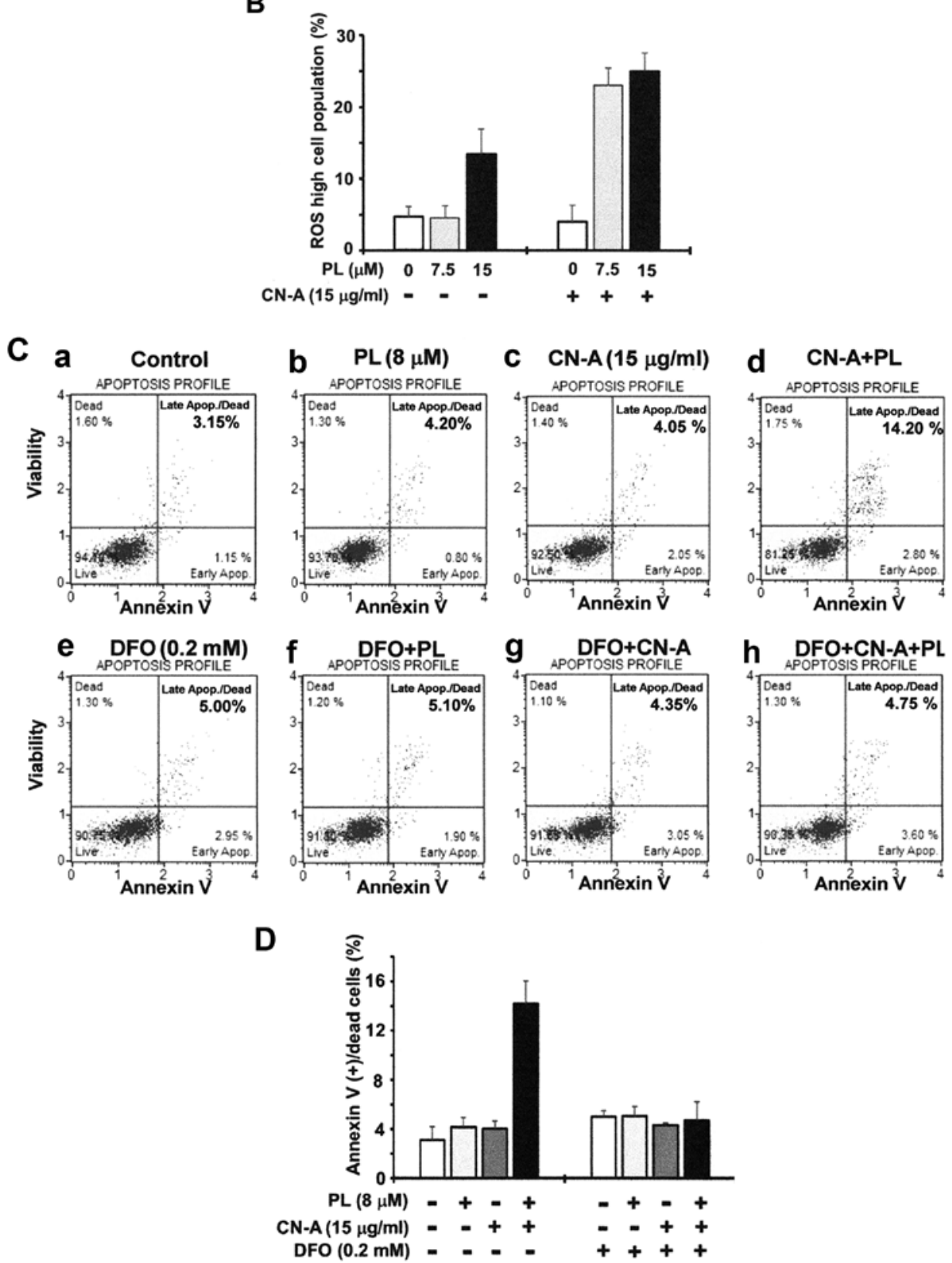

Figure 3. Effects of combined treatment with piperlongumine (PL) and cotylenin A (CN-A) on ROS generation and the induction of the apoptosis (Annexin V-positive) of MIAPaCa-2 cells. (A and B) MIAPaCa-2 cells were cultured with $7.5 \mu \mathrm{M}$ (gray columns) or $15 \mu \mathrm{M}$ (closed columns) PL in the absence or presence of $15 \mu \mathrm{g} / \mathrm{ml} \mathrm{CN}$-A for $4 \mathrm{~h}$. (C and D) MIAPaCa- 2 cells were treated with $8 \mu \mathrm{M}$ PL, $15 \mu \mathrm{g} / \mathrm{ml} \mathrm{CN}-\mathrm{A}$, or $8 \mu \mathrm{M}$ PL plus $15 \mu \mathrm{g} / \mathrm{ml} \mathrm{CN-A} \mathrm{in}$ the presence or absence of $0.2 \mathrm{mM}$ deferoxamine (DFO) for $16 \mathrm{~h}$. Cells were treated with DFO $2 \mathrm{~h}$ prior to CN-A and/or PL treatment. Values are expressed as the means \pm standard deviation of 3 measurements. 
A

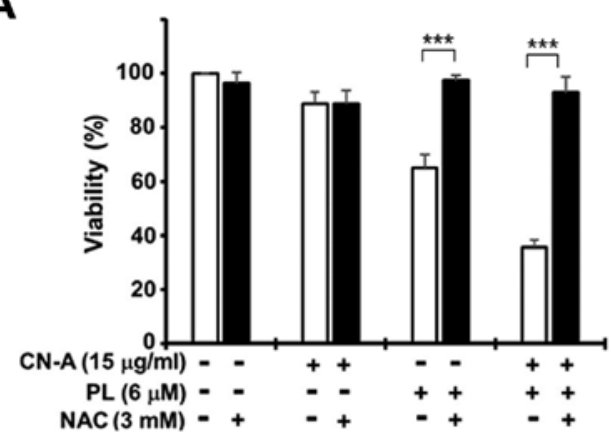

C

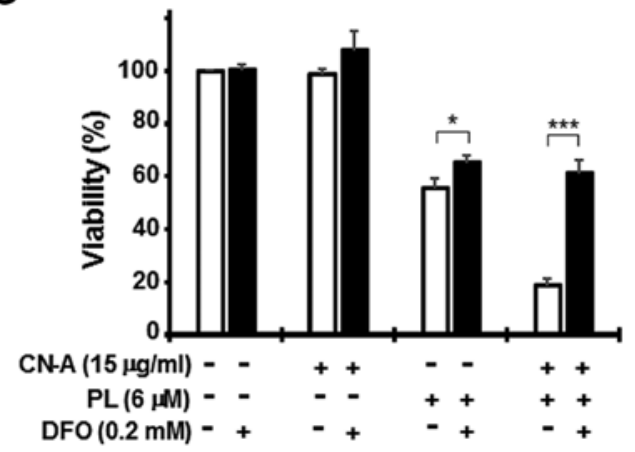

B

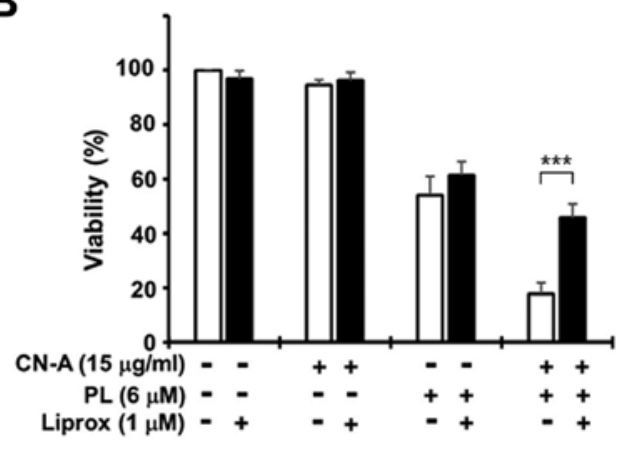

D

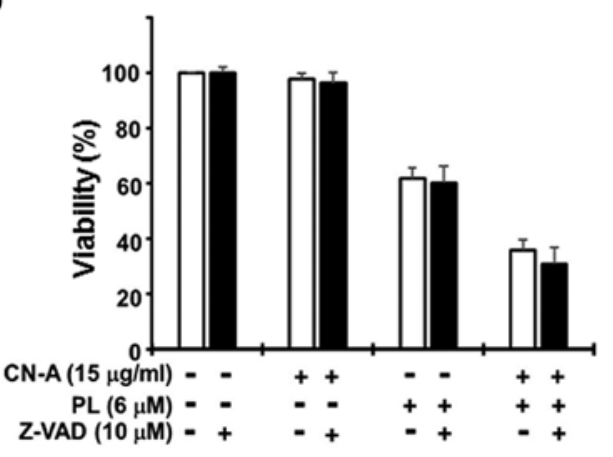

Figure 4. Effects of $N$-acetylcysteine (NAC), liproxstatin-1 (Liprox), deferoxamine (DFO), or Z-VAD-FMK (Z-VAD) on cotylenin A (CN-A) plus piperlongumine (PL)-induced cell death. PANC-1 cells were treated with $15 \mu \mathrm{g} / \mathrm{ml} \mathrm{CN-A,} 6 \mu \mathrm{M}$ PL, or $15 \mu \mathrm{g} / \mathrm{ml} \mathrm{CN}$-A plus $6 \mu \mathrm{M}$ PL in the presence or absence of (A) $3 \mathrm{mM}$ NAC, (B) $1 \mu \mathrm{M}$ Liprox, (C) $0.2 \mathrm{mM}$ DFO, or (D) $10 \mu \mathrm{M}$ Z-VAD for $16 \mathrm{~h}$. The cells were treated with NAC, Liprox, DFO, or Z-VAD for $2 \mathrm{~h}$ prior to $\mathrm{CN}-\mathrm{A}$ and/or PL treatment. Cell viability was assessed by MTT assay. Values are expressed as the means \pm standard deviation of 3 measurements. ${ }^{*}<0.05$ and ${ }^{* * * *} \mathrm{P}<0.001$

We measured the generation of ROS using the Muse cell analyzer. The MIAPaCa-2 cells were treated with $15 \mu \mathrm{g} / \mathrm{ml}$ $\mathrm{CN}-\mathrm{A}$ and/or 7.5 or $15 \mu \mathrm{M}$ PL for $4 \mathrm{~h}$ in order to induce ROS generation, and ROS levels were then examined using the Muse Oxidative Stress kit. Although CN-A $(15 \mu \mathrm{g} / \mathrm{ml})$ or $7.5 \mu \mathrm{M}$ PL alone did not increase the population of ROS-positive cells $(<5 \%)$, treatment with CN-A $(15 \mu \mathrm{g} / \mathrm{ml})$ plus $7.5 \mu \mathrm{PL}$ synergistically increased the population of these cells $(>20 \%)$ (Fig. 3A and B). At a higher concentration (15 $\mu \mathrm{M})$, PL alone significantly increased the population of ROS-positive cells $(\sim 13 \%)$, and treatment with PL $(15 \mu \mathrm{M})$ plus CN-A resulted in a further increase in the population of ROS-positive cells ( 25\%) (Fig. 3A and B).

Treatment with CN-A $(15 \mu \mathrm{g} / \mathrm{ml})$ plus PL $(6 \mu \mathrm{M})$ for $16 \mathrm{~h}$ markedly decreased PANC-1 cell viability to $\sim 20-30 \%$, while treatment with $\mathrm{CN}-\mathrm{A}$ alone did not significantly reduce cell viability and PL $(6 \mu \mathrm{M})$ alone moderately reduced viability to $55-70 \%$ (Fig. 4). Treatment with the ROS scavenger, NAC (3 mM), almost completely abrogated the reduction in cell viability induced by treatment with PL alone (Figs. 1A and 4A) or CN-A plus PL (Fig. 4A). Treatment with the ferroptosis inhibitor, Ferr-1 $(1 \mu \mathrm{M})$, clearly abolished the CN-A plus PL-induced death of the MIAPaCa-2 and PANC-1 cells (Fig. 5). Treatment with another ferroptosis inhibitor, Liprox (1 $\mu \mathrm{M}$ ), also protected the PANC-1 cells from CN-A plus PL-induced death (Fig. 4B). The iron chelator, DFO (0.2 mM), also markedly abollished CN-A plus PL-induced cancer cell death (Fig. 4C). Similar results were obtained with the
MIAPaCa-2 cells (data not shown). These results suggest that $\mathrm{CN}-\mathrm{A}$ effectively enhances PL-induced ferroptotic cancer cell death.

Although PL $(8 \mu \mathrm{M})$ or CN-A $(15 \mu \mathrm{g} / \mathrm{ml})$ alone only induced the death of (Annexin V-positive) MIAPaCa-2 cells to a limited extent at $16 \mathrm{~h}$, combined treatment with PL and $\mathrm{CN}-\mathrm{A}$ moderately induced (Annexin V-positive) MIAPaCa-2 cell death (14.2\%) (Fig. 3C and D). However, DFO (0.2 mM) completely abolished the induction of (Annexin V-positive) cell death indcued by CN-A plus PL (Fig. 3C and D), indicating that the induction of (Annexin V-positive) cell death was an iron-dependent form. Ferr-1 $(1 \mu \mathrm{M})$ also abolished the induction of (Annexin V-positive) cell death induced by $\mathrm{CN}-\mathrm{A}$ plus PL (data not shown). Furthermore, Z-VAD (a typical apoptosis inhibitor,) failed to protect the cells against $\mathrm{CN}-\mathrm{A}$ plus PL-induced death (Fig. 4D). Another apoptosis inhibitor, Q-VD-OPH, also failed to protect the cells against CN-A plus PL-induced cell death (data not shown). Combined treatment with $\mathrm{CN}-\mathrm{A}$ plus PL did not induce the expression of cleaved caspase- 3 when the cells were examined using an apoptosis assay lit (R\&D Systems) (data not shown). These results thus suggest that CN-A plus PL induced ferroptotic cancer cell death before the clear induction of apoptotic cell death. The necroptosis inhibitors, Nec-1 (Fig. 6A) and Nec-1s (data not shown), failed to suppress CN-A plus PL-induced cell death. Since a recent study reported that ferroptosis was involved in an autophagic cell death process (34), we examined the effects of the autophagy inhibitor, 3-MA (Fig. 6B). 3-MA partially, 
A

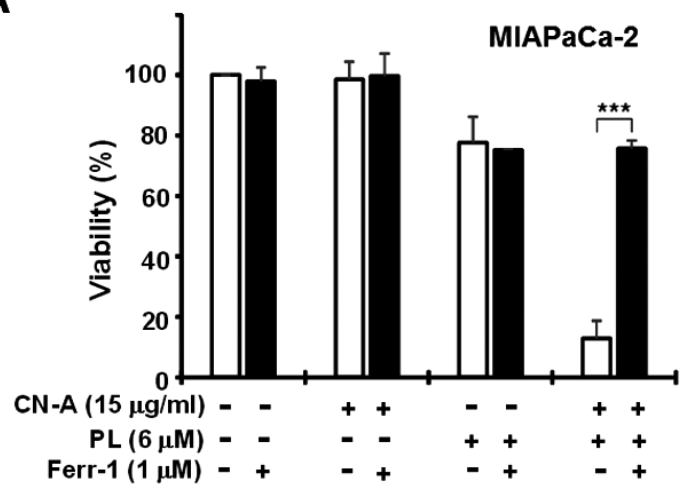

B



Figure 5. Effects of ferrostatin-1 (Ferr-1) on cotylenin A (CN-A) plus piperlongumine (PL)-induced cell death. The (A) MIAPaCa-2 and (B) PANC-1 cells were cultured with $15 \mu \mathrm{g} / \mathrm{ml} \mathrm{CN-A,} 6 \mu \mathrm{M} \mathrm{PL}$, or $15 \mu \mathrm{g} / \mathrm{ml} \mathrm{CN-A} \mathrm{plus}$ $6 \mu \mathrm{M}$ PL in the presence or absence of $1 \mu \mathrm{M}$ Ferr- 1 for $16 \mathrm{~h}$. The cells were treated with Ferr-1 for $2 \mathrm{~h}$ prior to CN-A and/or PL treatment. Cell viability was assessed by MTT assay. Values are expressed as the means \pm standard deviation of 3 measurements. ${ }^{* * *} \mathrm{P}<0.001$.

but reproducibly prevented PL-induced cell death and CN-A plus PL-induced cell death. Collectively, these results suggest that synergistic cell death induced by combined treatment with $\mathrm{CN}-\mathrm{A}$ and PL was mainly due to the induction of ferroptosis.

SSZ and PL synergistically induce the death of pancreatic cancer cells. Our preliminary results revealed that at relatively lower concentrations, erastin, one of the most representative ferroptosis inducers, co-operated with $\mathrm{PL}$ and/or CN-A to induce pancreatic cancer cell death (data not shown). We examined the effects of combined treatment with PL and clinical drugs (SSZ, sorafenib and auranofin) that have been reported to induce ferroptosis (30), and found that SSZ was the most effective enhancer of PL-induced ferroptotic cancer cell death (Fig. 7 and data not shown). We then investigated whether SSZ also potentiates PL-induced cancer cell death using several pancreatic cancer cells. The MIAPaCa-2, PANC-1, CFPAC-1 and BxPC-3 cells were cultured with or without SSZ, PL, or SSZ plus PL for $16 \mathrm{~h}$. Treatment with SSZ alone was shown as a closed circle at $0 \mu \mathrm{M}$ PL position (Fig. 7). SSZ and PL synergistically reduced the viability of the MIAPaCa-2, PANC-1 and CFPAC-1 cells (Fig. 7A-C). SSZ plus PL also more than additively induced the death of BxPC-3 cells (Fig. 7D), whereas the effects of this combination on viability were weaker than those in the MIAPaCa-2, PANC-1 and CFPAC-1 cells. On
A

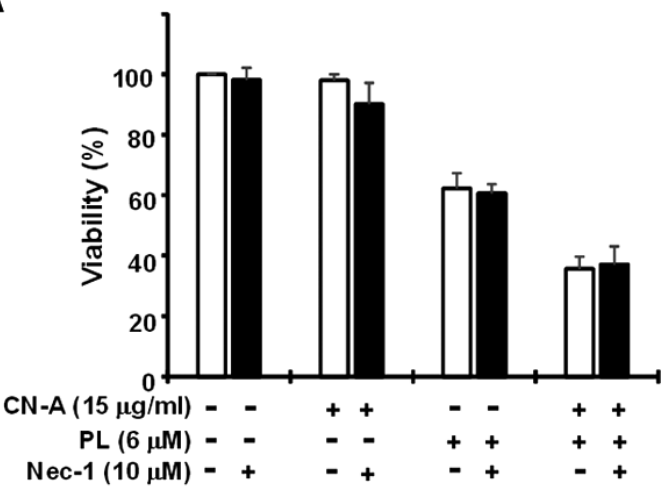

B

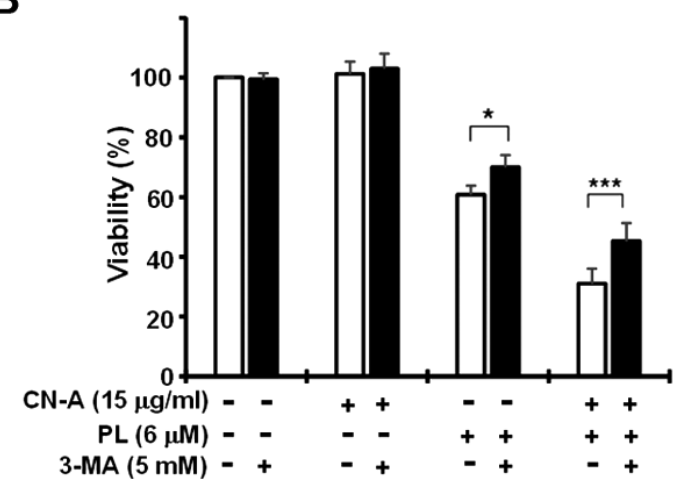

Figure 6. Effects of necrostatin-1 (Nec-1) or 3-methyladenine (3-MA) on cotylenin A (CN-A) plus piperlongumine (PL)-induced cell death. The PANC-1 cells were treated with $15 \mu \mathrm{g} / \mathrm{ml} \mathrm{CN}-\mathrm{A}, 6 \mu \mathrm{M}$ PL, or $15 \mu \mathrm{g} / \mathrm{ml} \mathrm{CN}-\mathrm{A}$ plus $6 \mu \mathrm{M} \mathrm{PL}$ in the presence or absence of (A) $10 \mu \mathrm{M} \mathrm{Nec}-1$ or (B) $5 \mathrm{mM}$ 3-MA for $16 \mathrm{~h}$. The cells were treated with Nec-1 or 3-MA for $2 \mathrm{~h}$ prior to $\mathrm{CN}-\mathrm{A}$ and/or PL treatment. Cell viability was assessed by MTT assay. Values are expressed as the means \pm standard deviation of 3 measurements. ${ }^{*} \mathrm{P}<0.05$ and ${ }^{* * *} \mathrm{P}<0.001$

the other hand, SSZ did not enhance PEITC (a ROS inducer)induced cell death and conversely inhibited PEITC-induced cell death (data not shown). Furthermore, PEITC inhibited the SSZ-induced death of pancreatic cancer cells (data not shown).

SSZ enhances the PL-induced ferroptotic death of pancreatic cancer cells. We then examined whether the synergistic induction of cancer cell death induced by combined treatment with SSZ and PL was due to the induction of ferroptosis. The MIAPaCa-2 cells were treated with $200 \mu \mathrm{SSZ}$ and/or 7.5 or $15 \mu \mathrm{PL}$ for $4 \mathrm{~h}$ to induce ROS generation, and ROS production was then examined using the Muse Oxidative Stress kit. Although SSZ at higher concentrations $(>300 \mu \mathrm{M})$ significantly increased the population of ROS-positive cells in our assay system (data not shown), SSZ $(200 \mu \mathrm{M})$ alone did not increase the population of ROS-positive cells $(<5 \%)$ (Fig. 8). PL $(7.5 \mu \mathrm{M})$ alone also did not increase the population of ROS-positive cells (Fig. 8). By contrast, treatment with SSZ $(200 \mu \mathrm{M})$ plus $7.5 \mu \mathrm{M}$ PL markedly increased the population of ROS-positive cells ( $>20 \%$ ) (Fig. 8). At a higher concentration $(15 \mu \mathrm{M}), \mathrm{PL}$ alone significantly increased the population of ROS-positive cells $(\sim 15 \%)$, and treatment with PL $(15 \mu \mathrm{M})$ plus SSZ $(200 \mu \mathrm{M})$ resulted in a further increase in the population of ROS-positive cells ( $>25 \%$ ) (Fig. 8). Treatment with the 

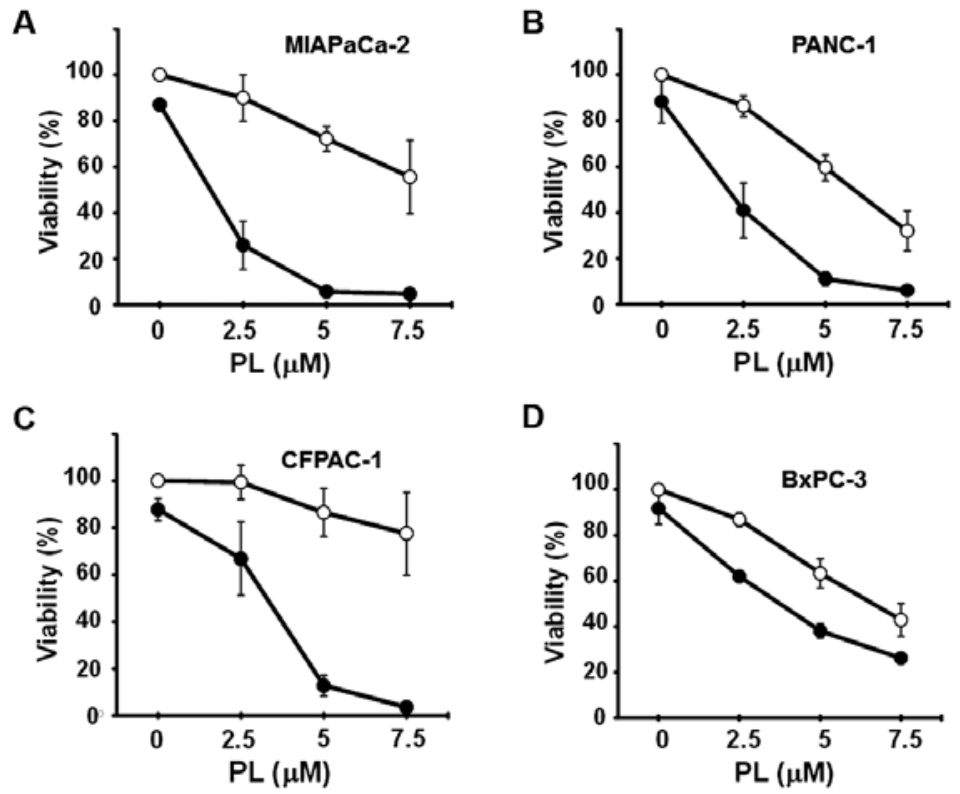

Figure 7. Effects of combined treatment with piperlongumine (PL) and sulfasalazine (SSZ) on the viability of MIAPaCa-2, PANC-1, CFPAC-1 and BxPC-3

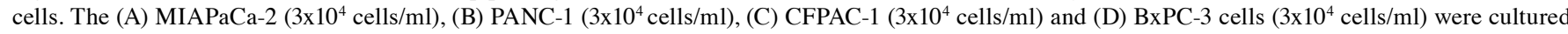
with PL in the absence (open circles) or presence of $200 \mu \mathrm{M}$ (closed circles) SSZ for $16 \mathrm{~h}$. Treatment with SSZ alone was shown as a closed circle at the $0 \mu \mathrm{M}$ PL position. Cell viability was then assessed by MTT assay. Values are expressed as the means \pm standard deviation of 3 measurements.

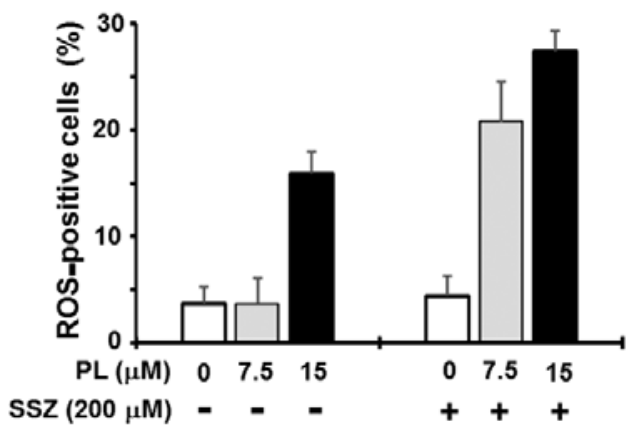

Figure 8. Effects of combined treatment with piperlongumine (PL) and sulfasalazine (SSZ) on ROS generation in the MIAPaCa-2 cells. MIAPaCa-2 cells were cultured with $7.5 \mu \mathrm{M}$ (gray columns) or $15 \mu \mathrm{M}$ (closed columns) $\mathrm{PL}$ in the absence or presence of $200 \mu \mathrm{M} \mathrm{SSZ}$ for $4 \mathrm{~h}$. Values are expressed as the means \pm standard deviation of 3 measurements.

ROS scavenger, NAC (3 mM), almost completely abolished the reduction in cell viability induced by treatment with PL alone or SSZ plus PL (Fig. 9A). The ferroptosis inhibitor, Ferr-1 $(1 \mu \mathrm{M})$, clearly abolished the SSZ plus PL-induced death of PANC-1 cells (Fig. 9B). The co-addition of the iron chelator, DFO $(0.2 \mathrm{mM})$, significantly blocked cell death induced by SSZ plus PL, demonstrating the iron dependency of cell death in PANC-1 cells (Fig. 9C). Similar results were obtained using the MIAPaCa-2 cells (data not shown). These results suggest that SSZ also effectively enhances PL-induced the ferroptotic death of pancreatic cancer cells.

Triple combined treatment with PL, CN-A and SSZ markedly inhibits the viability of pancreatic cancer cells. We examined the effects of triple combined treatment with PL, CN-A and SSZ on the viability of MIAPaCa-2 and PANC-1 cells (Fig. 10). We cultured these cancer cells in the presence or absence of SSZ (100 $\mu \mathrm{M}), \mathrm{CN}-\mathrm{A}(15 \mu \mathrm{g} / \mathrm{ml})$, or SSZ plus CN-A with or without
A

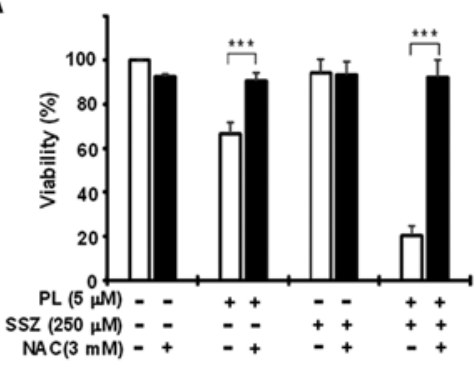

B

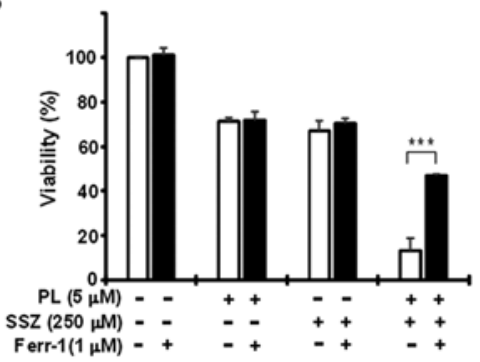

C

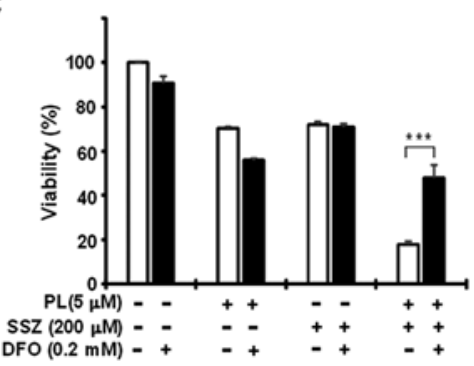

Figure 9. Effects of $N$-acetylcysteine (NAC), ferrostatin-1 (Ferr-1), or deferoxamine (DFO) on piperlongumine (PL) plus sulfasalazine (SSZ)-induced cell death. The PANC-1 cells were treated with $5 \mu \mathrm{M}$ PL, $200 \mu \mathrm{M} \mathrm{SSZ}$, or $5 \mu \mathrm{M}$ PL plus $200 \mu \mathrm{M} \mathrm{SSZ}$ in the presence or absence of (A) $3 \mathrm{mM}$ NAC, (B) $1 \mu \mathrm{M}$ Ferr-1, (C) or $0.2 \mathrm{mM}$ DFO for $16 \mathrm{~h}$. The cells were treated with NAC, Ferr-1, or DFO for $2 \mathrm{~h}$ prior to PL and/or SSZ treatment. Cell viability was assessed by MTT assay. Values are expressed as the means \pm standard deviation of 3 measurements. ${ }^{* * *} \mathrm{P}<0.001$. 
A



B

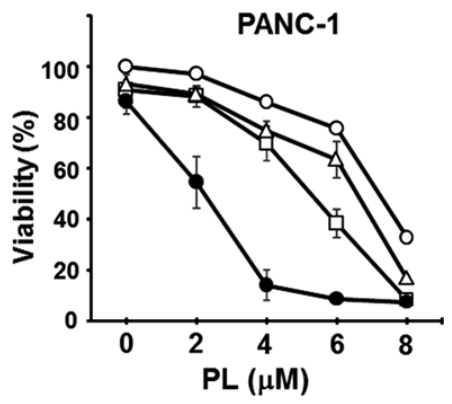

Figure 10. Effects of triple combined treatment with piperlongumine (PL), cotylenin A (CN-A) and sulfasalazine (SSZ) on the viability of MIAPaCa-2 and PANC-1 cells. (A) MIAPaCa-2 $\left(3 \times 10^{4}\right.$ cells $\left./ \mathrm{ml}\right)$ or (B) PANC-1 cells $\left(3 \times 10^{4}\right.$ cells $\left./ \mathrm{ml}\right)$ were cultured with PL at the indicated concentrations in the absence (open circles) or presence of $15 \mu \mathrm{g} / \mathrm{ml} \mathrm{CN}$-A (open squares), $100 \mu \mathrm{M} \mathrm{SSZ}$ (open triangles), or CN-A (15 $\mu \mathrm{g} / \mathrm{ml}) \mathrm{plus} \mathrm{SSZ} \mathrm{(100} \mu \mathrm{M})$ (closed circles) for $16 \mathrm{~h}$. Cell viability was then assessed by MTT assay. Values are expressed as the means \pm standard deviation of 3 measurements.

A

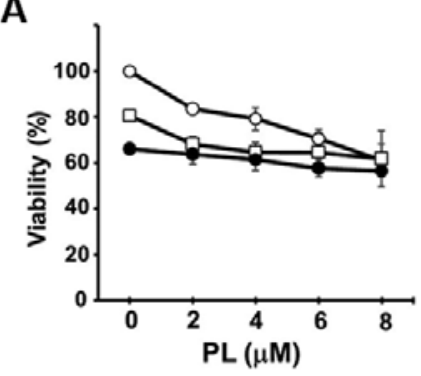

B

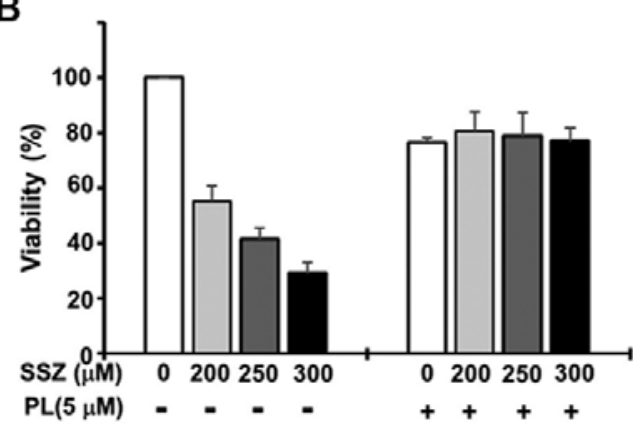

Figure 11. Effects of piperlongumine (PL), cotylenin A (CN-A), and/or sulfasalazine (SSZ)on the viability of mouse embryonic fibroblasts (MEFs). (A) MEFs $\left(3 \times 10^{4}\right.$ cells $\left./ \mathrm{ml}\right)$ were cultured with PL at the indicated concentrations in the absence (open circles) or presence of $15 \mu \mathrm{g} / \mathrm{ml} \mathrm{CN}$-A (open squares) or CN-A (15 $\mu \mathrm{g} / \mathrm{ml})$ plus SSZ $(150 \mu \mathrm{M})$ (closed circles) for $16 \mathrm{~h}$. Treatment with CN-A alone was shown as open square at the $0 \mu \mathrm{M}$ PL position. Cell viability was then assessed by MTT assay. (B) MEFs $\left(3 \times 10^{4}\right.$ cells $\left./ \mathrm{ml}\right)$ were cultured with SSZ at the indicated concentrations in the absence or presence of $5 \mu \mathrm{M}$ PL for $16 \mathrm{~h}$. Cell viability was then assessed by MTT assay. Values are expressed as the means \pm standard deviation of 3 measurements.

various concentrations of PL for $16 \mathrm{~h}$. Although PL alone at $2 \mu \mathrm{M}, \mathrm{CN}-\mathrm{A}$ alone at $15 \mu \mathrm{g} / \mathrm{ml}$, or SSZ alone at $100 \mu \mathrm{M} \mathrm{did}$ not influence the viability of the MIAPaCa-2 cells, and PL $(2 \mu \mathrm{M})$ plus $\mathrm{CN}-\mathrm{A}(15 \mu \mathrm{g} / \mathrm{ml})$ or PL $(2 \mu \mathrm{M})$ plus SSZ $(100 \mu \mathrm{M})$ only slightly reduced viability $(\sim 90 \%)$, triple combined treatment with PL $(2 \mu \mathrm{M}), \mathrm{CN}-\mathrm{A}(15 \mu \mathrm{g} / \mathrm{ml})$ and SSZ $(100 \mu \mathrm{M})$ synergistically reduced the viability of the MIAPaCa- 2 cells to $20 \%$ (Fig. 10A). The synergistic induction of cell death induced by triple combined treatment with PL, CN-A and SSZ was also observed in the PANC-1 cells (Fig. 10B). The cancer cell death induced by the triple combined treatment was also largely abolished by pre-treatment with the ferroptosis inhibitor, Ferr-1 (data not shown).

Effects of PL, CN-A and SSZ on the viability of MEFs. We examined the effects of combined treatment with $\mathrm{CN}-\mathrm{A}$ and PL on non-transformed MEFs. The MEFs (without the addition of 2-mecaptoethanol) were cultured with or without CN-A, $\mathrm{PL}$, or CN-A plus PL for $16 \mathrm{~h}$. The viability of the MEFs was mildly and dose-dependently decreased by PL, although the viability of the MEFs was $>60 \%$ in the presence of PL, even at a higher concentration $(8 \mu \mathrm{M})$ (Fig. 11A). Treatment with $\mathrm{CN}-\mathrm{A}$ alone was shown as open square at $0 \mu \mathrm{M}$ PL position. CN-A $(15 \mu \mathrm{g} / \mathrm{ml})$ or CN-A $(15 \mu \mathrm{g} / \mathrm{ml})$ plus SSZ $(150 \mu \mathrm{M}) \mathrm{did}$ not co-operate with PL to reduce the viability of the MEFs (Fig. 11A). Furthermore, we examined the effects of PL $(5 \mu \mathrm{M})$ on the SSZ-induced death of the MEFs. The MEFs were cultured with or without PL $(5 \mu \mathrm{M})$ in the absence or presence of various concentrations of SSZ for $16 \mathrm{~h}$. Although SSZ and PL synergistically induced the death of the pancreatic cancer cells (Fig. 7), as described above, PL almost completely abolished the SSZ-induced death of the MEFs (Fig. 11B).

\section{Discussion}

PL selectively induces the death of numerous cancer cell lines, as well as cancerous tumors in animal models, including pancreatic cancer, breast cancer and leukemia, but does not exhibit anti-proliferative behavior in non-transformed cells, thus rendering it a good candidate for cancer treatment (21-24). PL directly binds to and inhibits the antioxidant enzyme, glutathione S-transferase Pi 1, resulting in elevated intracellular ROS generation and subsequent apoptotic cell death in cancers with no apparent toxicity to normal cells $(21,25)$. Zou et al recently reported that PL interacted with thioredoxin reductase 1 to induce the ROS-mediated apoptosis of human gastric cancer cells (35). In addition, PL has been shown to promote cell death by activating several mechanisms, including apoptosis, autophagy and necrosis, affecting the PI3K/AKT/mTOR, p38/JNK, MEK/ERK and NF- $\mathrm{B}$ pathways $(22,27-29,36)$. In the present study, we found that PL alone induced the death of pancreatic cancer cells, at least in part, by the induction of ferroptosis, the execution of which requires the accumulation of ROS in an iron-dependent manner (16). Furthermore, 
we demonstrated that PL-induced ferroptotic cell death was markedly enhanced by $\mathrm{CN}-\mathrm{A}$ and/or SSZ in pancreatic cancer cells. These results support the potential of PL as an attractive therapeutic option that functions through different mechanisms from those already reported in pancreatic cancer cells.

We recently found that PEITC (a dietary anticarcinogenic compound and ROS inducer) in the presence of $\mathrm{CN}-\mathrm{A}$ induced ferroptotic cancer cell death in pancreatic cancer cells, whereas PEITC alone did not (20). These findings indicate the potential of finding other effective therapeutic compounds in combination with $\mathrm{CN}-\mathrm{A}$ to induce the ferroptotic death of pancreatic cancer cells. In the present study, we demonstrated that co-treatment with PL and CN-A induced synergistic cancer cell death in pancreatic cancer MIAPaCa- 2 and PANC-1 cells and that these effects on the viability of the cancer cells were largely canceled by ferroptotic inhibitors and iron chelator. We also unexpectedly found that the induction of pancreatic cancer cell death by PL alone at relatively higher concentrations was significantly reduced by ferroptotic inhibitors and the iron chelator. These results suggest that PL induces ferroptotic pancreatic cancer cell death and its effects are markedly enhanced by $\mathrm{CN}-\mathrm{A}$. Furthermore, we demonstrated that PL and SSZ (a clinical drug and ferroptosis inducer) synergistically induced the death of pancreatic cancer MIAPaCa-2, PANC-1 and CFPAC-1 cells (Fig. 7). Although combined treatment with CN-A plus PEITC (20) or CN-A plus PL similarly induced ferroptotic cancer cell death (Figs. 2 and 4-6), the effects of combined treatment with PEITC plus SSZ (data not shown) or PL plus SSZ (Figs. 7 and 9) differed markedly. PL and SSZ synergistically induced cancer cell death and these effects were largely abolished by the ferroptotic inhibitor, Ferr-1, or the iron chelator, DFO (Figs. 7 and 9), whereas PEITC inhibited SSZ-induced cancer cell death and SSZ did not enhance the PEITC-induced death of pancreatic cancer cells (data not shown). We found that the triple combined treatment with CN-A, PL and SSZ markedly reduced the viability of the MIAPaCa-2 and PANC-1 cells (Fig. 10). On the other hand, the viability of non-transformed MEFs was mildly decreased by PL, although the viability of the MEFs was $>60 \%$ in the presence of PL, even at a higher concentration $(8 \mu \mathrm{M})$. CN-A or CN-A plus SSZ did not co-operate with PL to reduce the viability of the MEFs. Furthermore, PL almost completely abolished the SSZ-induced death of the MEFs (Fig. 11). These results suggest that PL is superior to PEITC as a partner in combined treatment with $\mathrm{CN}$-A plus SSZ as a possible treatment regimen for pancreatic cancer.

The mechanisms underlying the interaction between CN-A and PL have not yet been elucidated in detail. Ferroptosis is regulated by several important events, such as ROS production, the reduction of glutathione, the inhibition of lipid hydroperoxidase GPX4 and the oxygenation of polyunsaturated phosphatidylethanolamines by 15-lipoxygenase $(16,17,32,33)$. In this study, we reported that $\mathrm{CN}-\mathrm{A}$ or SSZ (at lower concentrations) enhanced ROS production induced by PL (Figs. 3A and 8). The effect of CN-A or SSZ on other important ferroptosis-associated events in the presence of PL remains to be determined. Kwon et al reported that heme oxygenase-1 accelerated erastin-induced ferroptotic cell death (37). Heme oxygenase-1 is a major intracellular source of iron. Zinc protoporphyrin IV (a heme oxygenase-1 inhibitor) prevented erastin-triggered ferroptotic cancer cell death (37). Erastin increases the mRNA levels of heme oxygenase- 1 in HT-1080 fibrosarcoma cells (37). Lee et al reported that heme oxygenase- 1 influenced the differential responses of breast cancer and normal cells to PL (38). We found that CN-A $(15 \mu \mathrm{g} / \mathrm{ml})$ or PL (6 or $8 \mu \mathrm{M})$ markedly increased the mRNA levels of heme oxygenase-1 for $16 \mathrm{~h}$ in the PANC-1 cells (data not shown). These results suggest that $\mathrm{CN}-\mathrm{A}$ - and/or PL-induced heme oxygenase-1 plays a role in the induction of ferroptotic cancer cell death induced by CN-A plus PL.

As previously demonstrated, combined treatment with $\mathrm{CN}-\mathrm{A}$ and PEITC strongly induced cell death within 1 day, whereas treatment with synthetic $\mathrm{CN}$-A derivatives (ISIR-005 and ISIR-042) and PEITC did not exert synergistic effects on cell death (20). On the other hand, we previously reported that the synthetic CN-A-derivatives, ISIR-005 and ISIR-042, as well as CN-A in combination with certain bioactive agents, such as rapamycin and arsenic trioxide synergistically exerted antitumor effects in several cancer cells (12,39-41). We observed that combined treatment with synthetic CN-A derivatives (ISIR-005 and ISIR-042) and PL did not exert synergistic effects on cell death (data not shown). These results suggest that $\mathrm{CN}-\mathrm{A}$, but not the other $\mathrm{CN}-\mathrm{A}$ derivatives, specifically interacts with PEITC or PL, and induces the ferroptotic death of pancreatic cancer cells. Since only CN-A among $\mathrm{CN}-\mathrm{A}$ and its derivatives contains an epoxide ring, we synthesized a $\mathrm{CN}-\mathrm{A}$ derivative without the epoxide ring and investigated whether the $\mathrm{CN}-\mathrm{A}$ derivative without the epoxide ring enhanced the PL-induced ferroptotic death of PANC-1 cells. The $\mathrm{CN}-\mathrm{A}$ derivative without the epoxide ring did not enhance the PL-induced ferroptotic death of PANC-1 cells (Yamaguchi et al, unpublished data). These findings suggest that the epoxide ring of $\mathrm{CN}$-A plays an important role in enhancing PL-induced ferroptotic cell death.

Since pancreatic cancer is among the most aggressive human malignancies with a 5-year survival rate of $<10 \%$ despite the optimal treatments currently available, the development of novel and effective therapeutic agents or new effective combination regimens is essential, and more effective and safe chemotherapeutic treatments are required. In this study, we demonstrated that PL alone induced the ferroptotic death of pancreatic cancer cells and that combined treatment with PL plus CN-A and/or a lower dose of SSZ (approved for clinical use for several diseases, such as rheumarthritis and one of the known ferroptosis inducers) may further effectively induce the ferroptotic death of pancreatic cancer cells. On the other hand, the synergistic induction of cell death by PL and CN-A was not observed in MEFs, and SSZ did not enhance cell death induced by PL plus CN-A in MEFs. These results suggest that the triple combined treatment with PL, CN-A and SSZ is very effective against pancreatic cancer. Viswanathan et al (42) recently reported that therapy-resistant cancer cells are characterized by a dysregulated apoptotic cascade and exhibit an enhanced ability to undergo ferroptosis. Therefore, the triple combined treatment with PL, CN-A, and SSZ may also be effective against therapy-resistant pancreatic cancer cells.

\section{Acknowledgements}

Not applicable. 


\section{Funding}

This study was partly supported by a grant (16K10459) from the Ministry of Education, Culture, Sports, Science, and Technology of Japan and by a grant from the Shimane University 'SUIGAN' project.

\section{Availability of data and materials}

The analyzed data sets generated during the study are available from the corresponding author on reasonable request.

\section{Authors' contributions}

All authors contributed to the manuscript as follows: Conceptualization, YY, TK and SK; methodology, YY and TK; investigation, YY and TK; writing of original draft, YY and TK; writing, revisions (reviewing) and editing, TK and SK; funding acquisition and supervision, TK and SK. All authors have read and approved the final manuscript.

\section{Ethics approval and consent to participate}

Not applicable.

\section{Consent for publication}

Not applicable.

\section{Competing interests}

The authors declare that they have no competing interests.

\section{References}

1. Siegel RL, Miller KD and Jemal A: Cancer statistics, 2016. CA Cancer J Clin 66: 7-30, 2016

2. Han X, Saiyin H, Zhao J, Fang Y, Rong Y, Shi C, Lou W and Kuang T: Overexpression of miR-135b-5p promotes unfavorable clinical characteristics and poor prognosis via the repression of SFRP4 in pancreatic cancer. Oncotarget 8: 62195-62207, 2017.

3. Hidalgo M: Pancreatic cancer. N Engl J Med 362: 1605-1617, 2010.

4. Burris HA III, Moore MJ, Andersen J, Green MR, Rothenberg ML, Modiano MR, Cripps MC, Portenoy RK, Storniolo AM, Tarassoff P, et al: Improvements in survival and clinical benefit with gemcitabine as first-line therapy for patients with advanced pancreas cancer: A randomized trial. J Clin Oncol 15: 2403-2413, 1997.

5. Conroy T, Desseigne F, Ychou M, Bouché O, Guimbaud R, Bécouarn Y, Adenis A, Raoul JL, Gourgou-Bourgade S, de la Fouchardière $\mathrm{C}$, et al; Groupe Tumeurs Digestives of Unicancer; PRODIGE Intergroup: FOLFIRINOX versus gemcitabine for metastatic pancreatic cancer. N Engl J Med 364: 1817-1825, 2011.

6. Kroep JR, Pinedo HM, van Groeningen CJ and Peters GJ: Experimental drugs and drug combinations in pancreatic cancer Ann Oncol 10 (Suppl 4): 234-238, 1999.

7. Jakstaite A, Maziukiene A, Silkuniene G, Kmieliute K, Gulbinas A and Dambrauskas Z: HuR mediated post-transcriptional regulation as a new potential adjuvant therapeutic target in chemotherapy for pancreatic cancer. World J Gastroenterol 21: 13004-13019, 2015.

8. Zhong S, Qie S, Yang L, Yan Q, Ge L and Wang Z: S-1 monotherapy versus $S-1$ combination therapy in gemcitabine-refractory advanced pancreatic cancer. A meta-analysis (PRISMA) of randomized control trial. Medicine (Baltimore) 96: e7611, 2017.

9. Shaw AT, Winslow MM, Magendantz M, Ouyang C, Dowdle J, Subramanian A, Lewis TA, Maglathin RL, Tolliday N and Jacks T: Selective killing of K-ras mutant cancer cells by small molecule inducers of oxidative stress. Proc Natl Acad Sci USA 108: 8773-8778, 2011
10. Hezel AF, Kimmelman AC, Stanger BZ, Bardeesy N and Depinho RA: Genetics and biology of pancreatic ductal adenocarcinoma. Genes Dev 20: 1218-1249, 2006.

11. Honma Y, Ishii Y, Yamamoto-Yamaguchi Y, Sassa T and Asahi K: Cotylenin A, a differentiation-inducing agent, and IFN-alpha cooperatively induce apoptosis and have an antitumor effect on human non-small cell lung carcinoma cells in nude mice. Cancer Res 63: 3659-3666, 2003

12. Kasukabe T, Okabe-Kado J, Kato N, Sassa T and Honma Y: Effects of combined treatment with rapamycin and cotylenin A, a novel differentiation-inducing agent, on human breast carcinoma MCF-7 cells and xenografts. Breast Cancer Res 7: R1097-R1110, 2005.

13. Kasukabe T, Okabe-Kado J, Kato N, Honma Y and Kumakura S: Cotylenin A and arsenic trioxide cooperatively suppress cell proliferation and cell invasion activity in human breast cancer cells. Int J Oncol 46: 841-848, 2015.

14. Yang WS and Stockwell BR: Synthetic lethal screening identifies compounds activating iron-dependent, nonapoptotic cell death in oncogenic-RAS-harboring cancer cells. Chem Biol 15: 234-245, 2008.

15. Dixon SJ, Lemberg KM, Lamprecht MR, Skouta R, Zaitsev EM, Gleason CE, Patel DN, Bauer AJ, Cantley AM, Yang WS, et al: Ferroptosis: An iron-dependent form of nonapoptotic cell death. Cell 149: 1060-1072, 2012.

16. Yang WS and Stockwell BR: Ferroptosis: Death by lipid peroxidation. Trends Cell Biol 26: 165-176, 2016.

17. Latunde-Dada GO: Ferroptosis: Role of lipid peroxidation, iron and ferritinophagy. Biochim Biophys Acta 1861: 1893-1900, 2017.

18. Xiao D, Powolny AA, Moura MB, Kelley EE, Bommareddy A, Kim SH, Hahm ER, Normolle D, Van Houten B and Singh SV: Phenethyl isothiocyanate inhibits oxidative phosphorylation to trigger reactive oxygen species-mediated death of human prostate cancer cells. J Biol Chem 285: 26558-26569, 2010.

19. Hong Y-H, Uddin MH, Jo U, Kim B, Song J, Suh DH, Kim HS and Song YS: ROS accumulation by PEITC selectively kills ovarian cancer cells via UPR-mediated apoptosis. Front Oncol 5: 167, 2015.

20. Kasukabe T, Honma Y, Okabe-Kado J, Higuchi Y, Kato N and Kumakura S: Combined treatment with cotylenin A and phenethyl isothiocyanate induces strong antitumor activity mainly through the induction of ferroptotic cell death in human pancreatic cancer cells. Oncol Rep 36: 968-976, 2016.

21. Raj L, Ide T, Gurkar AU, Foley M, Schenone M, Li X, Tolliday NJ, Golub TR, Carr SA, Shamji AF, et al: Selective killing of cancer cells by a small molecule targeting the stress response to ROS. Nature 475: 231-234, 2011.

22. Dhillon H, Mamidi S, McClean P and Reindl KM: Transcriptome analysis of piperlongumine-treated human pancreatic cancer cells reveals involvement of oxidative stress and endoplasmic reticulum stress pathways. J Med Food 19: 578-585, 2016.

23. Jin HO, Park JA, Kim HA, Chang YH, Hong YJ, Park IC and Lee JK: Piperlongumine downregulates the expression of HER family in breast cancer cells. Biochem Biophys Res Commun 486: 1083-1089, 2017.

24. Alpay M, Yurdakok-Dikmen B, Kismali G and Sel T: Antileukemic effects of piperlongumine and alpha lipoic acid combination on Jurkat, MEC1 and NB4 cells in vitro. J Cancer Res Ther 12: 556-560, 2016.

25. Harshbarger W, Gondi S, Ficarro SB, Hunter J, Udayakumar D, Gurbani D, Singer WD, Liu Y, Li L, Marto JA, et al: Structural and biochemical analyses reveal the mechanism of glutathione S-transferase pi 1 inhibition by the anti-cancer compound piperlongumine. J Biol Chem 292: 112-120, 2017.

26. Chen SY, Liu GH, Chao WY, Shi CS, Lin CY, Lim YP, Lu CH, Lai PY, Chen HR and Lee YR: Piperlongumine suppresses proliferation of human oral squamous cell carcinoma through cell cycle arrest, apoptosis and senescence. Int J Mol Sci 17: 616, 2016.

27. Wang Y, Wang JW, Xiao X, Shan Y, Xue B, Jiang G, He Q, Chen J, $\mathrm{Xu} \mathrm{HG}$, Zhao RX, et al: Piperlongumine induces autophagy by targeting p38 signaling. Cell Death Dis 4: e824, 2013.

28. Liu QR, Liu JM, Chen Y, Xie XQ, Xiong XX, Qiu XY, Pan F, Liu D, Yu SB and Chen XQ: Piperlongumine inhibits migration of glioblastoma cells via activation of ROS-dependent p38 and JNK signaling pathways. Oxid Med Cell Longev 2014: 653732, 2014.

29. Chen Y, Liu JM, Xiong XX, Qiu XY, Pan F, Liu D, Lan SJ, Jin S, Yu SB and Chen XQ: Piperlongumine selectively kills hepatocellular carcinoma cells and preferentially inhibits their invasion via ROS-ER-MAPKs-CHOP. Oncotarget 6: 6406-6421, 2015. 
30. Xie Y, Hou W, Song X, Yu Y, Huang J, Sun X, Kang R and Tang D: Ferroptosis: Process and function. Cell Death Differ 23: 369-379, 2016

31. Sassa T, Tojyo T and Munakata K: Isolation of a new plant growth substance with cytokinin-like activity. Nature 227: 379, 1970.

32. Jiang L, Kon N, Li T, Wang S-J, Su T, Hibshoosh H, Baer R and Gu W: Ferroptosis as a p53-mediated activity during tumour suppression. Nature 520: 57-62, 2015

33. Hangauer MJ, Viswanathan VS, Ryan MJ, Bole D, Eaton JK, Matov A, Galeas J, Dhruv HD, Berens ME, Schreiber SL, et al: Drug-tolerant persister cancer cells are vulnerable to GPX4 inhibition. Nature 551: 247-250, 2017.

34. Ma S, Henson ES, Chen Y and Gibson SB: Ferroptosis is induced following siramesine and lapatinib treatment of breast cancer cells. Cell Death Dis 7: e2307, 2016.

35. Zou P, Xia Y, Ji J, Chen W, Zhang J, Chen X, Rajamanickam V, Chen G, Wang Z, Chen L, et al: Piperlongumine as a direct TrxR1 inhibitor with suppressive activity against gastric cancer. Cancer Lett 375: 114-126, 2016.

36. Wang Y, Wu X, Zhou Y, Jiang H,Pan S and Sun B: Piperlongumine suppresses growth and sensitizes pancreatic tumors to gemcitabine in a xenograft mouse model by modulating the NF-kappa B pathway. Cancer Prev Res (Phila) 9: 234-244, 2016.

37. Kwon MY, Park E, Lee SJ and Chung SW: Heme oxygenase-1 accelerates erastin-induced ferroptotic cell death. Oncotarget 6 : 24393-24403, 2015.
38. Lee HN, Jin HO, Park JA, Kim JH, Kim JY, Kim B, Kim W, Hong SE, Lee YH, Chang YH, et al: Heme oxygenase-1 determines the differential response of breast cancer and normal cells to piperlongumine. Mol Cells 38: 327-335, 2015.

39. Kawakami K, Hattori M, Inoue T, Maruyama Y, Ohkanda J, Kato N, Tongu M, Yamada T, Akimoto M, Takenaga K, et al: A novel fusicoccin derivative preferentially targets hypoxic tumor cells and inhibits tumor growth in xenografts. Anticancer Agents Med Chem 12: 791-800, 2012.

40. Kasukabe T, Okabe-Kado J, Haranosono Y, Kato N and Honma Y: Inhibition of rapamycin-induced Akt phosphorylation by cotylenin A correlates with their synergistic growth inhibition of cancer cells. Int J Oncol 42: 767-775, 2013.

41. Miyake T, Honma Y, Urano T, Kato N and Suzumiya J: Combined treatment with tamoxifen and a fusicoccin derivative (ISIR-042) to overcome resistance to therapy and to enhance the antitumor activity of 5-fluorouracil and gemcitabine in pancreatic cancer cells. Int J Oncol 47: 315-324, 2015.

42. Viswanathan VS, Ryan MJ, Dhruv HD, Gill S, Eichhoff OM, Seashore-Ludlow B, Kaffenberger SD, Eaton JK, Shimada K, Aguirre AJ, et al: Dependency of a therapy-resistant state of cancer cells on a lipid peroxidase pathway. Nature 547: 453-457, 2017. 